\title{
REVIEW
}

\section{p53: oncogene or anti-oncogene?}

\author{
David P. Lane ${ }^{1}$ and Sam Benchimol ${ }^{2}$ \\ ${ }^{\mathrm{I} I m p e r i a l ~ C a n c e r ~ R e s e a r c h ~ F u n d, ~ C l a r e ~ H a l l ~ L a b o r a t o r i e s, ~ S o u t h ~ M i m m s, ~ P o t t e r s ~ B a r, ~ H e r t s ~ E N 6 ~ 3 L D ~ U K ; ~}{ }^{2}$ The Ontario \\ Cancer Institute, University of Toronto, Toronto, Ontario, M4X 1K9 Canada
}

\section{The products of two groups of DNA tumor viruses bind p53}

p53, a 375-amino-acid nuclear phosphoprotein, was first detected because it formed a tight complex with the SV40 large-T antigen (Lane and Crawford 1979; Linzer and Levine 1979) and therefore was coimmunoprecipitated with anti-T antibodies from extracts of SV40transformed cells. This observation revealed the first example of such a complex between a viral oncogene and a host protein and served as a precedent for the discovery of a large number of protein-protein interactions between the products of oncogenes and other proteins. For example, other polyomavirus large- $\mathrm{T}$ antigens, including the $\mathrm{BK}, \mathrm{JC}$, and LPV proteins, but not the polyomavinus protein, were also found to complex with $\mathrm{p} 53$. Of intense interest was the finding that the adenovirus 5 $58,000-\mathrm{kD}$ E1B protein also bound p53 (Sarnow et al. 1982). Because the E1B gene product cooperates with the E1A gene product in cell transformation, but shows no obvious homology to SV40 large-T antigen, this result suggested that the transforming proteins of these two distinct DNA tumor virus families were targeting the same host protein as part of their transforming action. This idea has been greatly enhanced by recent work on the retinoblastoma $(\mathrm{Rb})$ gene. Like p53, the retinoblastoma protein $\mathrm{p} 105-\mathrm{Rb}$ is physically complexed to the oncogene products of different groups of DNA tumor viruses. The adenovirus E1A (Whyte et al. 1988) proteins, the polyomavirus large- $T$ antigens (DeCaprio et al. 1988), and the human papillomavirus E7 proteins (Dyson et al. 1989) all bind Rb through conserved sequence motifs. This conservation of function within the DNA tumor viruses suggests that modification of p53 and $\mathrm{Rb}$ function may be essential for their propagation (see Fig. 1).

Subsequent studies established that the p53 protein was present in minute concentrations in normal cells and tissues, but that high levels of the protein occurred in a large number of tumors and tumor cell lines. The basis for the high concentration of p53 in tumor cells appears, in many cases, to be a post-translational stabilization. This stabilization could be achieved by changes in the cellular environment, by complexing to other proteins (e.g., large $\mathrm{T}$ antigen), or by mutation of the $\mathrm{p} 53$ protein coding sequence (Finlay et al. 1988; Hinds et al. 1989).

The p53 protein has been conserved during evolution, and the gene has been isolated from man, rat, mouse, frog, chicken, and bony fish. The frog and rodent proteins bind tightly to SV40 large-T antigen, whereas the human and monkey proteins form a much less stable complex. Comparison of the amino acid sequences of all these p 53 proteins reveals five blocks of particularly highly conserved sequence (for review, see Jenkins and Sturzbecher 1988). Several of these blocks are important for the interaction with large- $T$ antigen, leading to the suggestion that they may represent sites of interaction with host cell proteins that are mimicked by large- $\mathrm{T}$ antigen.

\section{The transforming activity of the p53 gene}

Shortly after the successful cloning of murine p53 cDNAs, three groups reported that cotransfection of plasmids designed to express high levels of p53 with a plasmid encoding an activated ras gene would transform early-passage rodent cells (Eliyahu et al. 1984; Jenkins et al. 1984; Parada et al. 1984). High levels of p53 protein were detected in the p53 plus ras-transformed cells. The p53 gene could also act on its own to immortalize earlypassage rat chondrocytes (Jenkins et al. 1984). In the original reports of transformation by the p 53 gene, the p53 coding region was placed under the control of strong promoters and this was tacitly assumed to provide the activation to transformation that the expression of the endogenous chromosomal gene lacked. Indeed, in support of this idea, Jenkins et al. (1985) obtained significantly higher rates of transformation when using the RSV LTR than when using the SV40 early promoter-enhancer. Jenkins' group also showed that defectiveness of this SV40 promoter construct could be overcome by mutation of the p53 coding sequence. This important finding provided the first indication that mutation of the p53 amino acid sequence could enhance the transforming activity of the p53 protein. Thus, as was shown with other cellular proto-oncogenes, the transforming activity of p53 appeared to be activated by alterations in gene structure or gene expression. Other investigators reported that expression of p53 alone following transfection into established rodent cells rendered these cells tumorigenic (Eliyahu et al. 1985; Kelekar and Cole 1986; Tuck and Crawford 1989).

In an important experiment for this discussion, Wolf et al. $(1984 a, b)$ established that a line of Abelson virustransformed murine leukemic cells failed to express p53. Unlike p53-expressing sister cell lines, the p53-minus 
Lane and Benchimol

Polyomavirus

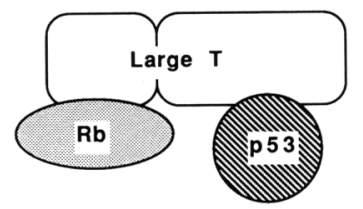

Adenovirus
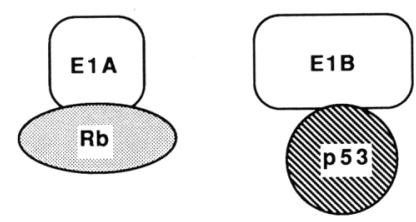

Papillomavirus
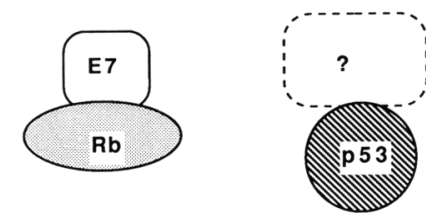

Figure 1. Complexes between the oncogenes of the DNA tumor viruses and cellular anti-oncogenes. The large $T$ antigens of the polyomaviruses bind both $\mathrm{Rb}$ and $\mathrm{p} 53$. The $\mathrm{Rb}$ binding site lies within the amino-terminal one-third of the protein and the p53 binding site in the carboxy-terminal two-thirds of the protein. In adenovirus, the binding activities are on separate polypeptides - E1A binds $\mathrm{Rb}$ and E1B binds $\mathrm{p} 53$. In papillomavirus, the $\mathrm{E} 7$ protein shows Rb binding activity in vitro but no report of binding of any papillomavirus protein to $\mathrm{p} 53$ has been published.

L12 cells failed to grow as a progressive tumor, and tumors induced by this cell line would only reach a certain size and then spontaneously regress. When p53 expression was restored in these cells after transfection of a p53 expression construct, the cells gave rise to progressive tumors (Wolf et al. 1984c). The conclusion from these studies was that the aberrant expression of the normal p53 protein brought about by transfection of constructs designed to overexpress the protein was a significant step on the road to cellular transformation. Thus, the p53 gene was designated a cell-encoded nuclear oncogene belonging to the same functional group as myc, myb, and fos. As explained below, this interpretation turned out to be incorrect, because all of the p53 constructs used in these experiments contained mutations in the coding region of the p53 gene that affect its biological activity.

\section{Only mutant p53 genes transform?}

Two sets of observations, both from one of our laboratories, cast doubt on the definition of normal p53 as a dominant oncogene. The first finding was that in Friend virus-induced murine erythroleukemia the p53 gene was a frequent target for mutation (Mowat et al. 1985; Chow et al. 1987; Rovinski et al. 1987; Munroe et al. 1988). Several of the leukemic cell clones simply failed to express p53 as a result of gross insertions or deletions at the p53 gene. The remaining clones expressed a grossly mutant product, as determined by expression of a truncated protein product involving deletion of the amino terminus or internal exons or by the expression of a fullsized p53 protein of altered antigenic phenotype. The second finding was that transfection of a simple genomic construct of p53 functioning from its own promoter seemed to be very effective as an immortalizing and ras-complementing oncogene, as were some of the mutant p53 genes cloned from the erythroleukemic cells (Rovinski and Benchimol 1988). These findings were difficult to understand because the first result implied a functional equivalence between absence of p53 expression and expression of a mutant p53 protein, whereas the second result suggested that the small perturbations in p53 expression resulting from positional effects or gene dosage may be sufficient to reveal its oncogenic potential.

At this point, a second set of studies emerged that clarifed the picture. Levine's and Oren's groups found that a cDNA clone for p53 derived from an F9 EC cell library failed to complement ras, whereas, in keeping with earlier studies, the genomic clone isolated from $\mathrm{BALB} / \mathrm{c}$ mouse liver and a number of cDNA clones derived from mouse tumor cell lines were competent in this assay (Finlay et al. 1988). Comparison of the sequences of these clones revealed a few codon changes. At the time that these sequences were published, these minor sequence differences did not attract great attention - the implicit conclusion being that they amounted to sequencing errors or polymorphisms. However, given the now clear-cut difference in the biological activity of the different clones, these sequence differences have been examined. The difference between the genomic clone that was able to complement ras and the F9 clone that could not was finally narrowed down to a change from valine to alanine at amino acid 135 (Eliyahu et al. 1988; Hinds et al. 1989).

But why was the genomic clone transforming? The publication of the sequence of frog p53 highlighted the problem (Soussi et al. 1987). Comparison of the human, mouse, and frog p53 sequences revealed five highly conserved blocks of amino acid sequence, and amino acid 135 was in one of these blocks. The F9 and five other mouse cDNAs, including one isolated from normal lymphocytes, and the human and frog CDNAs all encoded alanine at this position. These results strongly suggested that the genomic clone was a mutant. The laboratory that isolated this clone was able to confirm this deduction rapidly (Eliyahu et al. 1988). The conclusion then was that the wild-type p53 is unable to complement ras, but that the mutant could do so. Examination of the sequence and biological activity of a number of natural and synthetic mutants of p53 has confirmed and extended this conclusion. Many different point, deletion, and insertion mutations of p53 are able to activate the protein so that it can complement ras. Within the mutant activated cDNAs isolated from tumor DNA, the mutations are present selectively in one of the evolutionarily conserved boxes (Fig. 2). It is striking that point mutations of this kind have now proved to be a frequent 


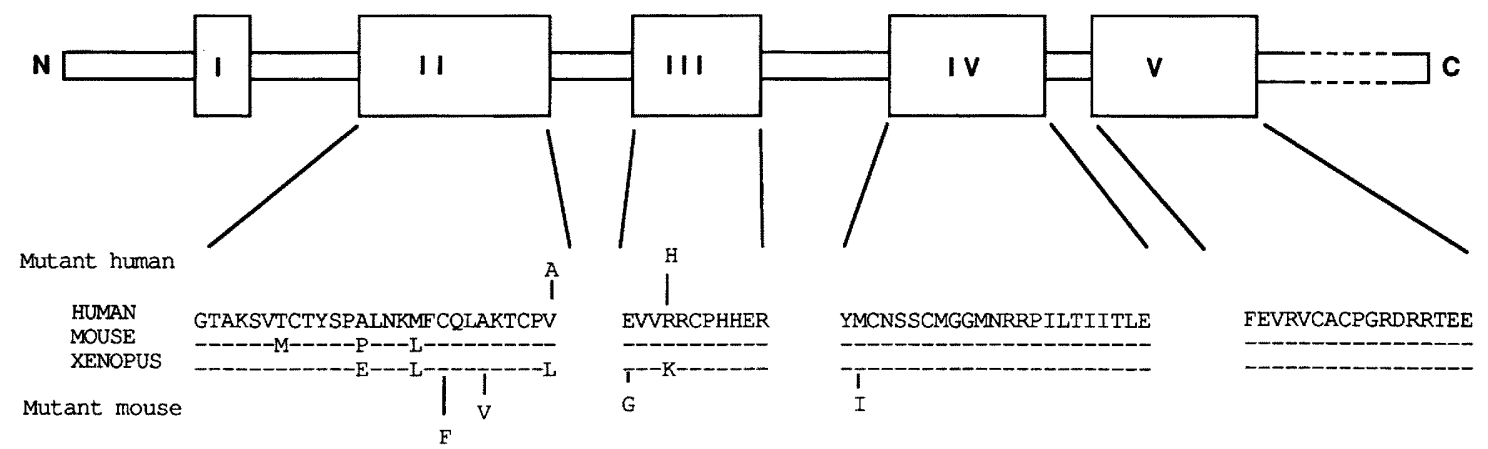

Figure 2. Schematic diagram of the structure of p53. The five blocks of evolutionarily conserved amino acid sequence are illustrated. The published point mutations found in human colon cancer and four mutations known to activate the dominant transforming action of the mouse protein are shown. All the mutations alter completely conserved amino acids.

feature of human cancer cells (see below). The two published mutations are also highlighted in Figure 2 and lie in conserved blocks two and three (Baker et al. 1989). Further work from Vogelstein's group has confirmed this finding (Nigro et al. 1989). A further 20 point mutations have been identified and these are found predominantly in the conserved regions.

\section{Properties of activated mutant p53s}

Although a range of different mutations are also able to activate p53 for ras complementation, biochemical and immunochemical comparisons of mutant and wild-type p53 proteins bearing point mutations strongly suggest that the different mutations have a similar effect on the protein's structure. First, in the mouse system, the mutant proteins have a much longer half-life than the wild type. Typically, the half-life is extended from 6-20 min to 4-8 hr. This change alone can account for the much higher steady-state levels of mutant p53 protein attained. Second, many of the mutant proteins complex to the hsp70 family of heat shock proteins (Sturzbecher et al. 1987, 1988a; Clark et al. 1988; Finlay et al. 1988). Third, the mutant proteins frequently lose expression of the conformationally sensitive epitope recognized by the murine p53-specific monoclonal antibody PAb246 (Milner and Cook 1986; Yewdell et al. 1986; Sturzbecher et al. 1987, 1988a; Clarke et al. 1988; Finlay et al. 1988) and instead express the conformationally resistant pan species-reactive epitope recognized by the PAb240 antibody (D. Lane, unpubl.). The mutant proteins fail to bind SV40 large-T antigen as efficiently as wild type and are also defective in their ability to inhibit SV40 replication in vivo (Braithwaite et al. 1987) or in vitro (Sturzbecher et al. 1988b) (see below).

\section{Mutations of p53 in neoplasia}

Comparison of the sequences of all tumor-derived murine p53 cDNAs suggests that they all contain activating mutations. These mutations are all missense mutations and are all localized to one or the other of the evolutionarily conserved blocks of amino acid sequence present in p53 (see Fig. 2). This extraordinary result is supported by the very high incidence of p53 proteins having the immunochemical and biochemical properties of the known mutant proteins in a wide range of tumor cell lines of both murine and human origin. Because of its very short half-life, the wild-type p53 protein is almost undetectable in conventional immunochemical and histochemical assays; thus, the ready detection of the protein is synonymous with mutation. Recently, following earlier studies from Crawford's laboratory (Crawford et al. 1984), Cattoretti et al. (1988) found that up to $40 \%$ of human mammary carcinoma biopsy samples showed clear immunocytochemical evidence for tumor-specific overexpression of the p53 protein. p53 overexpression was significantly associated with the high-grade estrogen receptor-negative tumors. Similarly, Van Den Berg et al. (1989) found that up to $30 \%$ of colon cancer showed clear immunocytochemical evidence for overexpression of $\mathrm{p} 53$.

In a very provocative report, Kopelovich and DeLeo (1986) found that the fibroblasts of patients with the inherited cancer susceptibility syndrome contained elevated levels of p53 compared to control individuals. This suggests that alteration of p53 expression may be the basis of the susceptibility, and it will be of great interest to determine if this is attributable to the presence of a point mutation in the p53 gene in the affected individuals. Support for this idea comes from the earlier finding that the cells of these individuals are peculiarly sensitive to SV40 transformation (Kopelovich 1984). This is consistent with these cells expressing a mutant p53, because cotransformation of a mutant $\mathrm{p} 53$ gene in the mouse system will enhance SV40 transformation (Michalovitz et al. 1986) and strain differences in susceptibility to SV40 transformation covary with p53 levels in precrisis mouse cells (Chen et al. 1984). Overexpression of p53 has also been detected in patients with leukemia or lymphoma (Koeffler et al. 1986; Smith et al. 1986; Lubbert et al. 1988).

The single copy of the human p53 gene is on chromosome $17 p$ and allele loss of $17 p$ is a very frequent feature of the major human cancers - breast cancer (Mackay et al. 1988), colon cancer (Baker et al. 1989), astrocytomas (James et al. 1989), and small cell lung carcinoma (Yokota et al. 1987). Loss of $17 \mathrm{p}$ is also seen in the bone 
marrow cells of chronic myeloid leukemia patients with blast crisis (Borgstrom et al. 1982). The crucial issue is whether this allele loss is associated with p53 or with another gene on this chromosomal segment. Recent results from Vogelstein's laboratory strongly suggest that the p53 gene is indeed the relevant locus (Baker et al. 1989; B. Vogelstein, pers. comm). The authors first analyzed a large number of colon cancer samples for selective allele loss using a range of specific DNA probes. In agreement with the cytogenetic data, loss of all or part of $17 \mathrm{q}$ was a very common feature. Using finer resolution probes, they established that the deletions always encompassed the region containing the p 53 gene. However, in common with the findings of many other groups, no gross rearrangement of the p53 gene on the remaining allele could be found. At this point, when most others would have given up, Vogelstein's group took the courageous step of determining the complete sequence of the p53 cDNA from two of the tumors. Remarkably, both tumors contained point mutations in the p53 gene, and both of these mutations were missense mutations localized to the conserved sequences of $\mathrm{p} 53$. This analysis has now been extended to a further 23 cases, and, in 20 of them, point mutations have been found. As before, the mutations are predominantly missense mutations and affect the most conserved sequences of p53 (Nigro et al. 1989.) These observations from the Vogelstein laboratory represent an enormous step forward in the understanding of the genetic basis of the common human cancers.

Other mechanisms may also operate in other tumor types to bring about a complete inactivation of both copies of the p53 gene. Gross rearrangements of the p53 gene have been detected in human osteogenic sarcoma (Masuda et al. 1987) and in the blast cells of patients with chronic myelogenous leukemia in blast crisis (Ahuja et al. 1989).

The recent findings in the mouse system and the initial results in the human system strongly suggest that alteration of $\mathrm{p} 53$ expression by mutation is the most frequent known genetic change in human cancer (Nigro et al. 1989; Takahashi et al. 1989; D.P. Lane unpubl.). It is striking that the tumor types where haploidization and mutation of the remaining p53 gene are found are also tumor types in which the same effects are seen on the Rb gene (Harbour et al. 1988; Yokota et al. 1988). These findings enhance the suggestion that functional connections may exist between the $\mathrm{Rb}$ gene and $\mathrm{p} 53$ /see below).

The normal function of $p 53$

The realization that most cell lines that express detectable amounts of p53 are probably expressing a mutant protein compromises much of the work on this protein in terms of trying to understand the normal role of $\mathrm{p} 53$ in the cell. A few pertinent facts suggest that this protein acts to regulate normal cell growth. Certain tumor cell lines of both human and mouse origin have been shown unequivocally to contain no functional p53 gene as a result of the presence of gross deletions or insertions in both alleles (Wolf et al. 1984a,b; Mowat et al. 1985; Ben-David et al. 1988). Thus, the protein is not essential for cell growth. The levels of p53 protein in normal cells and tissues are extremely low, only a few thousand molecules per cell (D. Lane, unpubl.) because of the protein's very short half-life. In contrast to the situation in the p53-deficient tumor cells, these few molecules are essential for the normal growth of cells that produce them. Both antibody microinjection (Mercer et al. 1984) and antisense RNA experiments (Shohat et al. 1987) suggest that inactivation of $\mathrm{p} 53$ in these cells prevents the normal mitotic response to serum growth factors. In developing models of the oncogenic action of mutant p53, it is important to realize how potent the wild-type molecule is in exerting its normal function.

The paradox described here suggests that to evolve to a viable p53-deficient state, a tumor cell must first undergo some other change that allows it to live without p53. The ability to grow independently of serum growth factors may be such a step.

\section{p53 as an anti-oncogene}

The evidence gathered thus far from cell culture studies and from tumor models indicates that p53 is essential for normal cell growth, perhaps as a negative regulator, and that its inactivation is necessary for the development of malignancy. This view of p53 as an anti-oncogene has now found direct experimental support (Finlay et al. 1989/. In an exceptionally interestng set of experiments, this group showed that cotransfection of a plasmid encoding wild-type p53 reduced the transforming potential of a mixture of plasmids encoding p53 and an activated ras gene. Although transfection of the mutant p53 and ras-encoding plasmids yielded an average of 20 foci of transformed rat embryo fibroblasts over seven separate transfections, inclusion of the wildtype p53-encoding plasmid in the transfection reduced this to an average of only one focus. Control experiments strongly suggest that this effect is mediated by the product of the wild-type gene and that it does not act simply to switch off expression of the mutant p53 gene. Even more remarkably, the wild-type p53-containing plasmid was also found to suppress transformation of the same cell type by a mixture of an activated ras gene and the adenovirus E1A gene. Whereas E1A plus ras transfection yielded 96 foci, inclusion of the wild-type p53 plasmid in the transfection mix reduced this to 20 foci. Most importantly, when 13 of these 20 transformants were analyzed, all contained the murine p53 gene but 10 out of the 13 failed to produce detectable murine p53. Two of the remaining cell lines produced a mutant murine p53. The mutations present in these p53 proteins showed some similarities to those seen earlier in the murine erythroleukemia model. The striking conclusion from these results is that there is an enormously strong selection pressure against the expression of the wild-type p53 in the transformed cells. These results could be explained in a fairly trivial way by postulating that the wild-type p53 protein is very toxic when intro- 
duced by DNA transfection. This explanation is not sufficient, however, because careful control experiments showed that when the wild-type p53 gene constructs were cotransfected with a plasmid encoding a selectable marker into primary cells, the wild-type p53 gene did not reduce the plating efficiency of the transfected cells. Importantly, the mutant p53-expressing plasmids actually increased plating efficiency and brought about immortalization. Thus, if the wild-type p53 protein is toxic, its toxicity is confined to transformed cells. Wildtype p53 in these assays seems to act as a potent antioncogene.

What is not clear in these studies is the role of endogenous p53 genes. Why are they unable to neutralize the transforming activity of E1A or mutant p53? It will be very important to sequence the endogenous genes in many different transformed cell lines so that the question of whether mutation of the endogenous p53 gene is essential for transformation can be addressed. In view of the very high frequency of $\mathrm{p} 53$ mutation found in cancer cells in vivo, it is possible that p53 mutation is an obligate step for cell transformation in vitro.

\section{Mutant p53 as dominant negative mutants-oncogene or anti-oncogene?}

The recent revelation of p53 as an anti-oncogene can be reconciled with the earlier reports of (mutant) p53 as a dominantly transforming oncogene by postulating that dominant negative mutations (Hershowitz 1987) in the p53 gene confer transforming activity in gene transfer assays. The mutant forms of p53 protein may act by binding to and neutralizing the product of the endogenous wild-type gene. Alternatively, mutant p53 may compete with the wild-type p53 for binding to its normal substrate. p53 can oligomerize, and in transfection experiments some immunochemical evidence exists for the formation of such mutant/wild-type hetero-oligomers (Eliyahu et al. 1988; Rovinksi and Benchimol 1988; Finlay et al. 1989). This idea is attractive because it fits with the concept that $\mathrm{T}$ antigen neutralizes $\mathrm{p} 53$ and $\mathrm{Rb}$ function by binding to them /see below). The mutant p53 then acts like a cellular $\mathrm{T}$ protein in complexing and neutralizing p53. Although this model is certainly interesting, it may not be sufficient. For example, it does not explain the ability of mutant p53 to enhance the oncogenic potential of p53-deficient cells (Wolf et al. 1984c). Also it is not clear why on such a model any advantage to the tumor would be gained by loss of the wild-type allele, yet this seems to be a frequent feature of both the mouse and human systems (Wolf et al. 1984a,b; Mowat et al. 1985). Of course, not all mutations that inactivate p53 function will act as dominant negatives. If the majority of mutations are truly recessive or of limited penetrance, and a second mutation is required to inactivate the homologous allele; this last point is easily explained.

However, to accommodate the observations of p53-deficient cells and the high frequency in mouse tumors of dominant negatives, it may be necessary to propose some additional oncogene activity of the mutant proteins acting alone, albeit that this activity may only be fully manifest in the absence of normal wild-type p53.

\section{Functions and connections, a role in replication for p53}

Recent results establish that the 553 protein can control SV40 DNA replication in vivo and in vitro. SV40 can replicate in primate cells but not in rodent cells and the same host range is also displayed by in vitro replication extracts derived from cells of these species. First, it was shown that murine p53 could block the binding of DNA polymerase- $\alpha$ to SV40 large-T antigen (Gannon and Lane 1987). On the basis of this observation, Braithwaite et al. (1987) looked for and found an inhibition of SV40 DNA synthesis in vivo when constructs able to express murine p53 were cotransfected with SV40 ori-containing plasmids into permissive $\mathrm{T}$ antigen-expressing cell lines (COS cells). Mutants of murine p53 that could not bind $\mathrm{T}$ (a frequent features of oncogenic activation) were unable to inhibit replication, and importantly, p53 from a permissive species (human) also showed no inhibitory effect. These findings have now been extended to the in vitro replication system /Sturzbecher et al. 1988b; Wang et al. 1989|. These results suggest that p53 may play a role in restricting the host range of SV40 virus but do they offer any insight to the normal function of p53 or its action as an oncogene? A simple model is to propose that wild-type p53 may block the binding of a $\mathrm{T}$ antigenlike host initiator protein to DNA polymerase- $\alpha$ to control host cell DNA replication. Then absence of p53 expression or mutation of $\mathrm{p} 53$ to a non-T/non-host protein binding form would release the cell from this control. Other explanations are possible, however, and indeed, there is some evidence that, in permissive cells, p53 may enhance some of the replication associated activities of $\mathrm{T}$ antigen (Tack et al. 1989).

\section{Do $p 53$ and $R b$ talk to each other?}

The foregoing discussion highlights the many similarities between the p53 and $\mathrm{Rb}$ gene products. As described above, the retinoblastoma protein p105-Rb, like $\mathrm{p} 53$, is physically complexed to the oncogene products of different groups of DNA tumor viruses. Genetic evidence strongly suggests that these interactions are important for the transforming action of these viral oncogenes. An attractive model has been that, as in the case of p53, the physical complex may act to neutralize the normal growth regulatory function of the $\mathrm{Rb}$ product. Recent surveys of human tumor-derived cell lines indicate that mutations in $\mathrm{Rb}$, like mutations in $\mathrm{p} 53$, may be a frequent occurrence in human neoplastic disease (Harbour et al. 1988; Yokota et al. 1988). These similarities between $\mathrm{p} 53$ and $\mathrm{Rb}$ extend to their biochemical properties and imply that both proteins may be components of the same regulatory pathway. Both proteins are not absolutely required for cell growth, as $\mathrm{Rb}$-negative tumor cell lines exist (Lee et al. 1987) in the same way as p53negative cell lines. If ElA function in transformation is 
mediated by $\mathrm{Rb}$ binding, then the ability of wild-type p53 to inhibit E1A-mediated transformation (Finlay et al. 1989) implies that there is a close functional connection between $\mathrm{Rb}$ and p53. In some way wild-type p53 is able to restore elements of growth regulation that are lost when E1A complexes to Rb. Multimeric complexes between $\mathrm{p} 53-\mathrm{T}$ and $\mathrm{Rb}$ have been detected, but there have been no reports of E1A p53 or p53-Rb complexes, perhaps indicating that these connections may be more subtle. It will certainly be of great interest to examine the state of the p53 gene in tumors with mutations in the $\mathrm{Rb}$ gene and vice-versa in order to determine if these two events are frequently associated. Similarly, it will be worthwhile to try and extend the biochemical similarities between the two proteins. Does a papillomavirus oncogene bind $\mathrm{p} 53$ ? Does $\mathrm{Rb}$ inhibit SV40 DNA replication? [SV40 is known to replicate with outstanding efficiency in cells transformed by adenovirus ElA and E1B where p53 is chelated by E1B binding and RB is chelated by E1A binding (Lebrowski et al. 1985; Lewis and Manley 1985/.] Can wild-type p53 convert p53-deficient tumor cells back to normal growth behavior as it appears $\mathrm{Rb}$ can for Rb-deficient cells (Huang et al. 1988)? Finally, is the p53 mutation the basis of any inherited cancer syndromes? The next few months should be very exciting as these questions are answered.

\section{Future directions}

These exciting results offer great hope for further insights to the genetic basis of human cancer from the study of the oncogenes of the DNA tumor viruses. They represent a vindication for the cancer scientist studying these models in much the same way as the discovery of mutation in the cellular proto-oncogenes in human cancer justified the pursuit of the oncogenic retroviruses. The increasing ease and sophistication of immunochemical detection of protein complexes offers real hope that further elements of the $\mathrm{Rb}$ and $\mathrm{p} 53$ networks will be uncovered. There is abundant evidence for other host proteins complexed to the products of the DNA tumor virus oncogenes, and many of these will make careful investigation wothwhile.

Further studies are needed to elucidate the role of p53 in normal and tumor cells. To a large extent the enigma surrounding p53 has begun to dissipate. It can be an oncogene in its mutant form or an anti-oncogene in its wild-type form. This realization blurs the distinction between the two groups of genes, and its suggests that the mutational activation of proto-oncogenes should be reexamined in other cases for evidence of dominant negative mutation.

\section{References}

Ahuja, H., M. Bar-Eli, S.H. Advani, S. Benchimol, and M.J. Cline. 1989. Alterations of the p53 gene and the clonal evolution of the blast crisis of chronic myelocytic leukemia. Proc. Natl. Acad. Sci. 86: 6783-6787.

Baker, S.J., E.R. Fearon, J.M. Nigro, S.R. Hamilton, A.C. Preisinger, J.M. Jessup, P. vanTuinen, D.H. Lodbetter, D.F.
Barker, Y. Nakamura, R. White, and B. Vogelstein. 1989. Chromosome 17 deletions and p53 gene mutations in colorectal carcinomas. Science 244: 217-221.

Ben-David, Y., V.R. Prideaux, V. Chow, S. Benchimol, and A. Bernstein. 1988. Inactivation of the p53 oncogene by internal deletion or retroviral integration in erythroleukemic cells induced by Friend leukemia virus. Oncogene 3: 179185.

Borgstrom, G.H., P. Vuopio, and A. de la Chapella. 1982. Abnormalities of chromosome No. 17 in myeloproliferative disorders. Cancer Genet. Cytogenet. 5: 123-125.

Braithwaite, A.W., H.-W. Sturzbecher, C. Addison, C. Palmer, K. Rudge, and J.R. Jenkins. 1987. Mouse p53 inhibits SV40 origin-dependent DNA replication. Nature 329: 458-460.

Cattoretti, G., F. Rilke, S. Andreola, L. D'Amato, and D. Delia. 1988. P53 expression in breast cancer. Int. I. Cancer 41: $178-183$.

Chen, S., G. Blanck, and R.E. Pollack. 1983. Pre-crisis mouse cells show strain-specific covariation in the amount of 54kilodalton phosphoprotein and in susceptibility to transformation by simian virus 40. Proc. Natl. Acad. Sci. 80: 5670 5674.

Chow, V., Y. Ben-David, A. Bernstein, S. Benchimol, and M. Mowat. 1987. Multistage Friend erythroleukemia: Independent origin of tumor clones with normal or rearranged p53 cellular oncogenes. J. Virol. 61: 2777-2781.

Clarke, C.F., K. Cheng, A.B. Frey, R. Stein, P.W. Hinds, and A.J. Levine. 1988. Purification of complexes of nuclear oncogene p53 with rat and Escherichia coli heat shock proteins: In vitro dissociation of hsc70 and dnaK from murine p53 by atp. Mol. Cell. Biol. 8: 1206-1215.

Crawford, L.V., D.C. Pim, and P. Lamb. 1984. The cellular protein p53 in human tumors. Mol. Biol. \& Med. 2: 261-272.

DeCaprio, J.A., J.W. Ludlow, J. Frigge, J.-Y. Shew, C.-M. Huang, W.-H. Lee, E. Marsillo, E. Paucha, and D.M. Livingstone. 1988. SV40 large tumor antigen forms a specific complex with the product of the retinoblastoma susceptibility gene. Cell 54: 275-283.

Dyson, N., P.M. Howley, K. Manger, and E. Harlow. 1989. The human papillomavirus-16 E7 oncoprotein is able to bind to the retinoblastoma gene product. Science 243: 934-936.

Eliyahu, D., A. Raz, P. Gruss, D. Givol, and M. Oren. 1984. Participation of p53 cellular tumour antigen in transformation of normal embryonic cells. Nature 312: 646-649.

Eliyahu, D., D. Michalovitz, and M. Oren. 1985. Overproduction of p53 antigen makes established cells highly tumorigenic. Nature 316: $158-160$.

Eliyahu, D., N. Goldfinger, O. Pinhasi-Kimhi, G. Shaulsky, Y. Shurnik, N. Arai, V. Rotter, and M. Oren. 1988. Meth A fibrosarcoma cells express two transforming mutant p53 species. Oncogene 3: 313-321.

Finlay, C.A., P.W. Hinds, T.-H. Tan, D. Eliyahu, M. Oren, and A.J. Levine. 1988. Activating mutations for transformation by $\mathrm{p} 53$ produce a gene product that forms on hsc70-p53 complex with an altered half life. Mol. Cell. Biol. 8: 531539.

Finlay, C.A., P.W. Hinds, and A.J. Levine. 1989. The p53 protooncogene can act as a suppressor of transformation. Cell 57: $1083-1093$

Gannon, J.V. and D.P. Lane. 1987. p53 and DNA polymerase $\alpha$ compete for binding to SV40 T antigen. Nature 329: 456458.

Harbour, J.W., S.L. Lai, J. Whang-Peng, A.F. Gazdar, J. Minna, and F.J. Kaye. 1988. Abnormalities in structure and expression of the human retinoblastoma gene in SCLC. Science 241: 353-357. 
Hershowitz, I. 1987. Functional inactivation of genes by dominant negative mutations. Nature 329: 219-222.

Hinds, P., C. Finlay, and A.J. Levine. 1989. Mutation is required to activate the p53 gene for cooperation with the ras oncogene and transformation. J. Virol. 63: 739-746.

Huang, H.-K.S., J.-K. Yee, J.-Y. Shew, P.-L. Chen, R. Bookstein, T. Friedman, E.Y.-H.P. Lee, and W.-H. Lee. 1988. Suppression of the neoplastic phenotype by replacement of the RB gene in human cancer cells. Science 242: 1563-1566.

James, C.D., E. Carlbom, M. Nordenskjold, V.P. Collins, and W.K. Cavanee. 1989. Mitotic recombination of chromosomes 17 in astrocytomas. Proc. Natl. Acad. Sci. 86: 28582862.

Jenkins, J.R., K. Rudge, and G.A. Currie. 1984. Cellular immortalization by a cDNA clone encoding the transformation-associated phosphoprotein p53. Nature 312: 651-654.

Jenkins, J.R., K. Rudge, P. Chumakov, and G.A. Currie. 1985. The cellular oncogene p53 can be activated by mutagenesis. Nature 317: 816-818.

Jenkins, J.R. and H.- . Sturzbecher. 1988. The p53 oncogene. In The oncogene handbook (ed. E.P. Reddy, A.M. Skalka, and T. Curran|, pp. 403-423. Elsevier Science Publications, Amsterdam.

Kelekar, A. and M.D. Cole. 1986. Tumorigenicity of fibroblast lines expressing the adenovirus Ela, cellular p53, or normal c-myc genes. Mol. Cell. Biol. 6: 7-14.

Koeffler, H.P., C. Miller, M.A. Nicolson, J. Raynard, and R.A. Bosselman. 1986. Increased expression of p53 protein in human leukemia cells. Proc. Natl. Acad. Sci. 83: 40354039.

Kopelovich, L. 1984. Skin fibroblasts from humans genetically predisposed to colon cancer are abnormally sensitive to SV40. Cancer Invest. 2: 333-338.

Kopelovich, L. and A.B. DeLeo. 1986. Elevated levels of p53 antigen in cultured skin fibroblasts from patients with hereditary adenocarcinoma of the colon and rectum and its relevance to oncogenic mechanisms. IN I C 77: 1241-1246.

Lane, D.P. and L.V. Crawford. 1979. T-antigen is bound to host protein in SV40-transformed cells. Nature 278: 261-263.

Lebkowski, J.S., S. Lancy, and M. Calos. 1985. Simian virus 40 replication in adenovirus transformed human cells antagonizes gene expression. Nature 317: 169-171.

Lee, W.-H., J.-Y. Shew, F.D. Hong, T.W. Sery, L.A. Donoso, L.-J. Young, R. Bookstein, and E.Y.-H.P. Lee. 1987. The retinoblastoma susceptibility gene encodes a nuclear phosphoprotein associated with DNA binding activity. Nature 329: 642-645.

Lewis, E.D. and J.L. Manley. 1985. Repression of simian virus 40 early transcription by viral DNA replication in human 293 cells. Nature 317: 172-175.

Linzer, D.I.H. and A.J. Levine. 1979. Characterization of a $54 \mathrm{~K}$ dalton cellular SV40 tumor antigen present in SV40 transformed cells and uninfected embryonal carcinoma cells. Cell 17: 43-52.

Lubbert, M., C.W. Miller, L.V. Crawford, and H.P. Koeffler. 1988. p53 in chronic myelogenous leukemia. J. Exp. Med. 167: $873-886$

Mackay, J., C.M. Steel, P.A. Elder, and A.P.M. Forrest. 1988. Allele loss on short arm of chromosome 17 in breast cancers. Lancet II: $1384-1385$.

Masuda, H., C. Miller, H.P. Koeffler, H. Battifora, and M.J. Kline. 1987. Rearrangement of the p53 gene in human osteogenic sarcomas. Proc. Natl. Acad. Sci. 84: 7716-7719.

Mercer, W.E., C. Avignolo, and R. Baserga. 1984. Role of the p53 protein in cell proliferation as studied by microinjection of monoclonal antibodies. Mol. Cell. Biol. 4: 276-281.
Michalovitz, D., D. Eliyahu, and M. Oren. 1986. Overproduction of protein p53 contributes to simian virus 40 -mediated transformation. Mol. Cell. Biol. 6: 3531-3536.

Milner, J. and A. Cook. 1986. The cellular tumour antigen p53: Evidence for transformation-related immunological variants of p53. Virology 154: 21-30.

Mowat, M., A. Cheng, N. Kicumca, A. Bernstein, and S. Benchimol. 1985. The arrangements of the cellular p53 gene in erythroleukaemic cells transformed by Friend virus. Nature 314: 633-636.

Munroe, D.G., B. Rovinski, A. Bernstein, and S. Benchimol. 1988. Loss of highly conserved domain on p53 as a result of gene deletion during Friend virus-induced erythroleukemia. Oncogene 2: 621-624.

Nigro, J.M., S.J. Baker, A.C. Preeisinger, J.M. Jessup, R. Hostetter, K. Cleary, S.H. Bigner, N. Davidson, S. Baylin, P. Devilee, T. Glover, F.S. Collins, A. Weston, R. Modali, C.C. Harris, and B. Vogelstein. 1989. Mutations in p53 gene occur in diverse human tumor types. Nature 342: 705-708.

Parada, L.F., H. Land, R.A. Weinberg, D. Wolf, and W. Rotter. 1984. Cooperation between gene encoding p53 tumour antigen and ras in cellular transformation. Nature 312: 649651.

Rovinski, B., D. Munroe, J. Peacock, M. Mowat, A. Bernstein, and S. Benchimol. 1987. Deletion of $5^{\prime}$-coding sequences of the cellular p53 gene in mouse erythroleukemia: A novel mechanism of oncogene regulation. Mol. Cell. Biol. 7: 847853.

Rovinski, B. and S. Benchimol. 1988. Immortalization of rat embryo fibroblasts by the cellular p 53 oncogene. Oncogene 2: 445-452.

Sarnow, P., Y.S. Ho, J. Williams, and A.J. Levine. 1982. Adenovirus E1b-58kd tumor antigen and SV40 large tumor antigen are physically associated with the same $54 \mathrm{Kd}$ cellular protein in transformed cells. Cell 28: 387-394.

Shobat, O., M. Greenberg, D. Reisman, M. Oren, and V. Rotter. 1987. Inhibition of cell growth mediated by plasmids encoding p53 anti-sense. Oncogene 1: 277-283.

Smith, L.J., E.A. McCulloch, and S. Benchimol. 1986. Expression of the p53 oncogene in acute myeloblastic leukemia. $J$. Exp. Med. 164: 751-761.

Soussi, T., C. Caron de Fromentel, M. Mechali, P. May, and M. Kress. 1987. Cloning and characterisation of a cDNA from Xenopus laevis coding for a protein homologous to human and murine p53. Oncogene 1: 71-78.

Sturzbecher, H.- ., P. Chumakov, W.J. Welch, and J.R. Jenkins. 1987. Mutant p53 proteins bind p53 hsp $72 / 73$ cellular heatshock-related proteins in SV40-transformed monkey cells. Oncogene 1: 201-211.

Sturzbecher, H.-W., C. Addison, and J.R. Jenkins. 1988a. Characterization of mutant $\mathrm{p} 53$-hsp $72 / 73$ protein-protein complexes by transient expression in monkey COS cells. Mol. Cell. Biol. 8: 3740-3747.

Sturzbecher, H.-W., R. Brain, T. Maimets, C. Addison, K. Rudge, and J.R. Jenkins. 1988b. Mouse p53 blocks SV40 DNA replication in vitro and downregulates $T$ antigen DNA helicase activity. Oncogene 3: 405-413.

Tack, L.C., J.H. Wright, S.P. Deb, and P. Tegtmeyer. 1989. The p53 complex from monkey cells modulates the biochemical activities of simian virus 40 large $\mathrm{T}$ antigen. $J$. Virol. 63: $1310-1317$.

Takahashi, T., M.M. Nau, I. Chlba, M.J. Birrer, R.K. Rosenberg, N. Levitt, H. Pass, A.F. Gazdar, and J.D. Minna. 1989. p53: A frequent target for genetic abnormalities in lung cancer. Science 246: 491-494.

Tuck, S.P. and L.V. Crawford. 1989. Overexpression of normal 
human p53 in established fibroblasts leads to their tumorigenic conversion. Oncogene Res. 4: 81-89.

Van Den Berg, F.M., A.J. Tigges, M.E.I. Schipper, F.C.A. Den Harog-Jager, W.G.M. Kroes, and J.M.M. Walboomers. 1989. Expression of the nuclear oncogene p53 in colon tumours. $f$. Pathol. 157: 193-199.

Wang, E.H., P.N. Friedman, and C. Prives. 1989. The murine p53 protein blocks replication of SV40 DNA in vitro by inhibiting the initiation functions of SV40 large $\mathrm{T}$ antigen. Cell 57: 379-392.

Whyte, P., K. Buchovich, J. Horowitz, S. Friend, M. Raybuck, R. Weinberg, and E. Harlow. 1988. Association between an oncogene and an anti-oncogene; the adenovirus E1A proteins bind to the retinoblastoma gene product. Nature 334: 124129.

Wolf, D., S. Admon, M. Oren, and V. Rotter. 1984a. Abelson murine leukemia virus-transformed cells that lack p53 protein synthesis express aberrant p53 mRNA species. Mol. Cell. Biol. 4: 552-558.

. 1984b. Major deletions in the gene encoding the p53 tumor antigen cause lack of p53 expression in HL-60 cells. Proc. Natl. Acad. Sci. 82: 790-794.

Wolf, D., N. Harris, and V. Rotter. 1984c. Reconstitution of p53 expression in a nonproducer Ab-MuLV-transformed cell line by transfection of a functional p53 gene. Cell 38: 119-126.

Yewdell, J.W., J.V. Gannon, and D.P. Lane. 1986. Monoclonal antibody analysis of p53 expression in normal and transformed cells. $J$. Virol. 59: 444-452.

Yokota, J., M. Wada, Y. Shimosato, M. Terada, and T. Sugimura. 1987. Loss of heterozygosity of chromosomes 3, 13, and 17 in small-cell carcinoma and on chromosome 3 in adenocarcinoma of the lung. Proc. Natl. Acad. Sci. 84: 92529256.

Yokota, J., T. Akiyama, Y.- .T. Fung, W.F. Benedict, Y. Namba, M. Hanaoka, M. Wada, T. Terasaki, Y. Shimosato, T. Sugimura, and M. Terada. 1988. Altered expression of the retinoblastoma $(R B)$ gene in small-cell carcinoma of the lung. Oncogene 3: 471-475. 


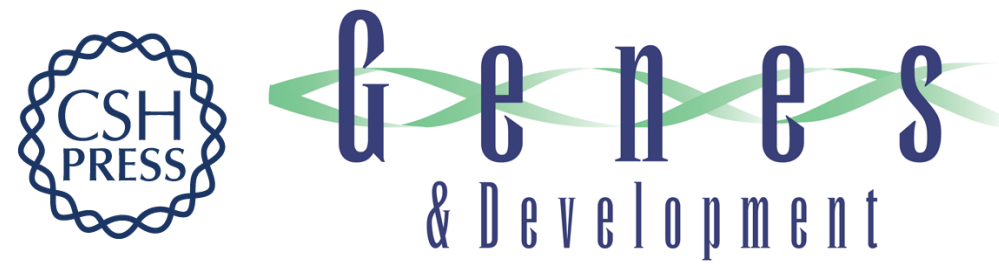

\section{p53: oncogene or anti-oncogene?}

D P Lane and S Benchimol

Genes Dev. 1990, 4:

Access the most recent version at doi:10.1101/gad.4.1.1

References This article cites 64 articles, 25 of which can be accessed free at: http://genesdev.cshlp.org/content/4/1/1.full.html\#ref-list-1

\section{License}

Email Alerting

Receive free email alerts when new articles cite this article - sign up in the box at the top Service right corner of the article or click here.

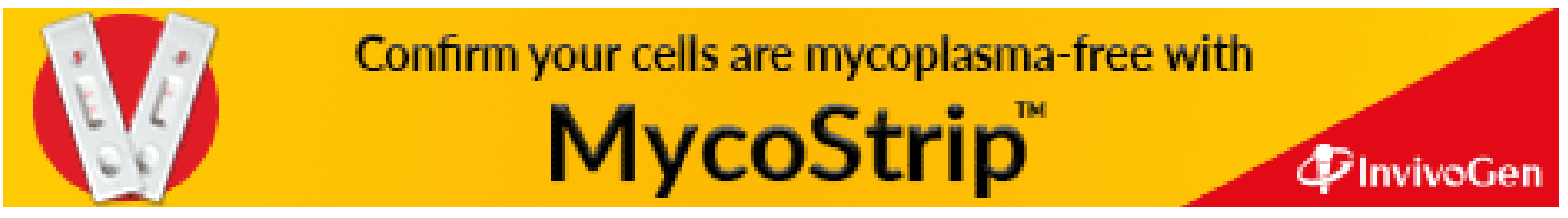

